Contributions to Indian Sociology (NS)

Vol. 11 No. 1 (1977)

\title{
Higher education as status stabilizer: students in Bangalore
}

\author{
N. JAYARAM \\ Bangalore University
}

Urban stratification represents one of the complex areas of sociological analysis in India. What is most impressive about it is that we know so little about it. The available empirical evidence, however, is consistent in demonstrating the overall stability of status structure in urban India (see e.g., Sovani 1966; Jorapur 1971; and Dubey 19/5). In this paper an attempt has been made at examining the role of higher education which is essentially an urban phenomenon in stabilizing the social status structure in urban India, by analyzing the social background of students entering higher and professional education in a metropolis.

\section{Problem}

The positive relation between the number of years of education on the one hand, and occupational achievement and the acquisition of elite status on the other, has been observed to be so pronounced and ubiquitous in urban areas in industrial and industrializing societies as to be accepted as a sociological axiom. Accordingly, there is a great deal of demand for admission to institutions of higher education as evidenced by the number of applications received for admission (Rudolph and Rudolph 1972: 26). Since education is still a 'scarce good' (Palmier 1967: 167), only a small percentage of eligible applicants eventually succeed in securing admission. In spite of the rapid rise in enrolment at the tertiary level of education in India, the percentage of people receiving higher education is still very small (Myrdal 1968: 1780).

Admission to the courses for which there is a burgeoning popular demand is, in principle, based strictly on merit and, in some institutions, merit is

${ }^{1}$ I am grateful to Dr C. Rajagopalan and Dr Satish Saberwal for their invaluable comments on an earlier draft of this paper. 1 am also thankful to Miss K. Sujatha for her help in processing the data. 
decided on the basis of an all-India entrance examination. Such admissions are seemingly free from all invidious discrimination. However, there is ample evidence to believe that admission to institutions of higher learning is influenced by some factors which are 'not in any essential way' related to either 'possession of adequate ability' or 'a record of satisfactory previous school work' (Wolfle 1965: 216-17). In this connection, Husen's observation that 'in competitive selections wide latitude is allowed to social factors' (1970: 123), though based on Swedish data, seems to be of far wider application.

The net result of the operation of socio-economic and cultural factors in admission to educational institutions has been that higher education, especially of the professional and prestigious types, has become the virtual monopoly of a select stratum of the society, which is invariably at the vertex of the stratification pyramid (Palmier 1967: 167 and Myrdal 1968: 1808). The resulting 'differences in level of educational attainment according to social background' have been shown to be 'indeed high in all countries when college level is considered' (Boudon 1974: xi, 44, see also 62).

The existing inequalities in educational opportunities have two consequences of a far wider concern. In the first place, though it is true that 'unequal life-chances are both cause and effect of unequal educational opportunities' (Floud and Halsey 1965:7) and both, social and educational inequalities, reinforce one another (Myrdal 1968: 1805 and 1765-66), there is no denying that in a developing country 'educational inequalities become, in effect, fundamentally determinant of all social inequality' (Floud and Halsey 1965: 3-4). Equally important is the mass of 'wasted academic ability' resulting from the fact that higher education is too limited and enjoyed by the wrong people (Young 1961: 35).

Since the publication of Who Shall Be Educated? in 1944 (Warner et al. 1944), there has been a tremendous theoretical and empirical preoccupation with this theme. In India, however, the interest in the study of education in relation to social stratification and mobility is comparatively recent (M.S.A. Rao 1967: 127), though some analyses of the social background of students in institutions of higher learning are available.

'At the University of Delhi the students came almost entirely from the middle and upper classes, and there were almost no graduates from the working classes or among the very poor of the middle classes' (V.K.R.V. Rao 1961: 2-3). Shah (1961: 41) found that the Hindu Gujarati male students of the M.S. University of Baroda 'largely belong to upper and middle socio-economic strata'. In Mysore city, Chitra (1970) found that undergraduate women students from the upper strata had greater opportunities for higher education than those from the middle or lower strata. 
The high social selectivity of students in institutions of professional education is evident also in Sharma (1972 and 1976).

The significance of caste as a factor influencing recruitment to higher and professional education has been recognized for a long time by social scientists. Various studies have shown that it is generally the children of higher castes who are able to take advantage of educational opportunities (Shah 1961 and Misra 1961). Brahmins, who were the traditionally privileged caste group (Myrdal 1968: 1627) and who were the earliest to respond to modern education (Misra 1961: 158 and 147-210 and Chitra 1972: 154), still seem to be the dominant caste with reference to higher education, being the single majority caste group in various institutions of higher learning, only to be followed by non-Brahmin higher castes' (Chitra 1970 and 1972 and Sharadamma and Parvathamma 1968: 52). This trend seems to have persisted despite various efforts to reduce Brahmin domination in the realm of education (Chitra 1972 and Dushkin 1974). It is also important to note that the representation of the scheduled castes, tribes and other backward caste groups in institutions of higher education is miniscule (Gore et al. 1970: 62-65). In some institutions, like the Indian Institute of Technology, during certain academic years, not a single scheduled caste/tribe student was enrolled (Rajagopalan and Jaspal Singh 1968: 3, and King 1970: 1470).

In addition to caste, there are some other social factors which influence education beyond schooling. Thus, the educational background of the family or, rather, the father's education, has been found to be a significant factor in accessibility to higher/professional education. Ahmad (1974: 185), for example, found a predominance of university educated parents or at least fathers in her sample of undergraduate women students in Delhi. Hooda (1968) found a majority of the parents of Bombay collegians to have been 'sufficiently' or 'moderately' educated. Similar observations apply to students in Indian Institute of Technology (Rajagopalan and Jaspal Singh 1968: 3 and King 1970: 1470) and medical colleges (Sharadamma and Parvathamma 1968: 53).

Occupation of the parents-or of the father, to be specific-seems to be the most significant factor influencing admission to higher education, because of its close correlation with education and income. Ahmad (1974: 185-86) found that an overwhelming majority of her sample of women students came from families of senior administrative and managerial personnel, senior professionals, industrialists, etc. Similar observations have also been made of university students in Delhi (Khusro 1967: 76-77) and Baroda (Shah 1961: 41), medical students in Mysore (Sharadamma and Parvathamma 1968: 53), and the Indian Institue of Technology (Rajagopalan and Jaspal Singh 1968: 4) and post-graduate management (Sharma 1972: M65-66) students; and the all-India field study of the National Coun- 
cil of Educational Research and Training (Gore et al. 1970: 77-82) confirms this.

Since higher education, especially of the professional type, is expensive, one could suppose that the economic condition of the family is an important factor influencing admission to higher and professional education. However, research findings on this point are not conclusive. While Ahmad (1974: 186), Chitra (1970), Rajagopalan and Jaspal Singh (1968: 4), King (1970: 1470), Shah (1961: 41), and Sharma (1972 and 1976) have found that their samples of students tend to be drawn from more or less 'high' income groups, Khusro (1967: 39) has found family income not to be necessarily an important factor. However, since 'the possibility of underestimation of income cannot be ruled out' (Khusro 1967: 39), it is safe to accept the former findings.

Turning to the various aspects of inequality of educational opportunity, it has been observed that in general, less attention is paid to the education of girls than of boys. In some courses, women do not find any representation at all, although there is no formal bar against their admission (Rajagopalan and Jaspal Singh 1968: 3). Even the few girls who do avail of higher education are from the upper strata of the society (Mehta 1970, Chitra 1970 ànd 1972, and Ahmad 1974: 185-86).

Students from expensive public schools and English medium private schools predominate in institutions of higher and professional education (Rajagopalan and Jaspal Singh 1968: 5, King 1970: 1470, Sharma 1972: M65-66, and Ahmad 1974: 187-89). But it should also be noted here that it is normally only children of the upper strata who avail of such education, which is almost entirely denied to the lower strata and to those in rural areas (R.P. Singh 1972: 24-36 and De Souza 1974).

Finally, students in the more important institutions of higher education come predominantly from urban areas (Shah 1961: 41, Rajagopalan and Jaspal Singh 1968: 1, Di Bona 1970: 80, and Sharma 1972 and 1976).

While the foregoing studies have dealt with the socio-economic and cultural background of students in the institutions of higher education, surprisingly little attention has been paid to the larger implications of the findings for social stratification in urban India. This paper is devoted to such an attempt. First we shall establish the role of higher education as status stabilizer in general by analyzing fresh data on the social origins of students in institutions of higher and professional education in a metropolis. Following this, we shall examine the theme more closely by focusing attention on the pattern of occupational inbreeding among students entering one of the most sought after courses of education in India (as also in many other countries), namely, medical education. 


\section{Social Origins of Students}

The data presented in this paper are part of a larger study of the reciprocal relationship between education and social stratification (Jayaram 1976). These are based on personal interviews with 344 students in higher and professional education selected by systematic random sampling from four institutions in Bangalore: ${ }^{2}$ an Institute deemed to be a University under Section 3 of the U.G.C. Act, a few post-graduate science departments of Bangalore University, a private and a government medical college. The chief reason for sampling these institutions is the very heavy demand for the courses they offer, which are prelusory to higher professional and administrative careers.

The various socio-economic factors to be considered here include sex of the students; their religion and caste; the educational, occupational and income background of their family; whether their origin is rural or urban; and the medium of instruction and the type of schooling they have had. However, 'the fact that the variables are discussed separately does not mean that they work independently. Quite the contrary, their effects are always intertwined' and, moreover, 'these factors are to some extent compensatory' (Wolfle 1965: 217).

$\operatorname{Sex}$

It has been argued that enlightened womanhood is one of the important prerequisites for modernization. The evidence suggests, however, that educational opportunities become available more narrowly to girls than to boys: nearly 75 per cent of the students in the total sample $(\mathrm{N}=344)$ are boys and only 26.16 per cent are girls. Girls find absolutely no representation in the post-graduate technology course, while their representation in research (18.18 per cent) and post-graduate liberal science $(21.67$ per cent) is also small. However, they are better represented in medicine, forming 34.5 per cent of the total medical students in the sample $(\mathrm{N}=200)$. Further, they are better represented in the government medical college (37.6 per cent) compared to the private medical college ( 29.33 per cent). This may be due to the predominantly local origin of the students in the former college and a lack of adequate hostel accommodation in the latter.

Moreover, compared to men students, women students in the sample are younger, their proportion in the sample tends to increase as we come down the age groups: it would seem that the drop-out rate for women is higher in higher education though not necessarily in professional education, as

${ }^{2}$ The total sample $(\mathrm{N}=344)$ consists of 44 research scholars, 60 post-graduate liberal ş̧ience students, 40 post-graduate technology students, 125 government medical college students, and 75 private medical college students. 
they maintain their proportion better in medicine.

No doubt, the traditional view of women and the associated prejudice, and also the early indifference on the part of the government inhibited their education (Mehta 1970: Ch 6, and Chitra 1972: 154). But,

even where specifically religious objections to the education of women are absent, limited familial resources must be expended first on boys whose potential contribution to the family economy is likely to be greater (Foster 19/1: 27).

In this context, one may distinguish between education as 'a productive investment' and 'a consumption luxury'. 'Most parents see education of boys as an investment for it prepares them for their potential roles as bread-winners' and 'education is not viewed either by the women themselves or by their parents as a productive investment,' it is rather an expenditure, a consumption luxury, which whenever necessary should be avoided (Ahmad 1974: 183 and 197). Added to this is the fact that neither the women students themselves have any definite career objective nor their parents have any expectations from their education (Mehta 1970: 33 and Ahmad 1974: 194-96). This fact probably explains the striking relation between the level of female representation and their socio-economic status. $^{3}$

\section{Religion and Caste}

It is seen that a predominant majority of our sample students ( 77.04 per cent) are Hindus, consistently with their percentage in the total population of the country (i.e., 82.72 per cent). Christians are the next largest religious community in the sample, i.e., 18.31 per cent, most of whom are pursuing medicine, largely in the private medical college, a Christian denominational institution. Muslims, and some other religious communities, though few in the sample, are better represented in the government medical college and the university departments. Women find better representation among Christians ( 36.51 per cent) than among Hindus (24.53 per cent); and there is no Muslim women in the sample.

Table 1 presents the caste background of the sample students. Given the great diversity of castes in this urban sample, comparison of students in terms of specific castes or in a hierarchical context would be cumbersome, and consequently, various castes are classified into three analytical categories, namely, Brahmins, non-Brahmins and the lower castes. In spite

${ }^{3}$ The question of relevance of women's education is an important consideration that makes any discussion of inequality of educational opportunity on sex lines really significant. For a brief discussion of this theme, see Ahmad (1974: 191-200). 
of some oversimplification involved, this classification seems to be adequate.

TABLE 1

RELIGION AND CASTE BACKGROUND OF STUDENTS

\begin{tabular}{lccccc}
\hline & Research & $\begin{array}{c}\text { Post- } \\
\text { Graduare } \\
\text { Students }\end{array}$ & $\begin{array}{l}\text { Pedivate } \\
\text { College } \\
\text { Students }\end{array}$ & $\begin{array}{l}\text { Movernment } \\
\text { College } \\
\text { Students }\end{array}$ & Total \\
& & & & & \\
\hline Hindu & 81.1 & 96.0 & 32.0 & 86.4 & 77.0 \\
Christian & 18.9 & 1.0 & 65.4 & 4.8 & 18.3 \\
Jain & - & 2.0 & - & 1.6 & 1.2 \\
Muslim & - & 1.0 & 1.3 & 4.8 & 2.3 \\
Others & - & - & 1.3 & 2.4 & 1.2 \\
Of 265 Hindus: & 62.2 & 54.2 & 62.5 & 63.9 & 60.0 \\
Brahmins & 35.1 & 38.5 & 29.2 & 29.6 & 33.6 \\
Non-Brahmin & 2.7 & 5.2 & - & 4.6 & 4.1 \\
Lower-caste & - & 2.1 & 8.3 & 1.9 & 2.3 \\
No response & & & & & \\
\hline
\end{tabular}

Note: Only percentage distributions are given in all the tables.

Of the 265 Hindus, 60 per cent are Brahmins and 33.58 per cent are non-Brahmins. With the lower castes forming only 4.15 per cent of the sample and 2.27 per cent declining to disclose their caste identity, the predominance of Brahmin and other upper castes in higher education is amply confirmed.

Course-wise, Brahmins tend to gravitate towards the professional and prestigious types of education. While they find higher representation in the technological course within the post-graduate category (forming 68.42 per cent of the 38 Hindus in that sample), they are more or less equally represented in medicine and research (forming 63.64 per cent and 62.16 per cent of the respective Hindu samples). Non-Brahmins, on the other hand, find better representation in the liberal science courses within the post-graduate category (forming 46.55 per cent) of the Hindus in that sample). Of the 11 lower caste students, five are in medicine, three in liberal science, two in technological course and one in research.

In terms of sex, though male students predominate all through, their predominance is least in the case of Brahmins and highest in the case of lower castes, i.e., the percentage of women students compared to men students is more in the case of Brahmins (25.79 per cent) than among the non-Brahmins (21.35 per cent) and the lower castes (18.18 per cent). Thus, 
it is clear that whatever inroads the non-Brahmins have made in higher education have been very largely by their men.

Given the well-known tendency of educational inequalities to persist over time (Foster 1971: 15), the roots of the foregoing can be readily found in the past. In pre-British India and also during the early phase of the British rule literary education was generally the monopoly of the upper castes (Misra 1961: 148). The first apparent jolt to this traditional system of education, which had contributed to the perpetuation and reinforcement of the traditional order based on an inequalitarian ideology, came in the last quarter of the eighteenth century with the introduction of the British or Western system of education based on universalistic criteria of recruitment (Chitra 1972: 152). Though the Britishers were basically concerned with creating a class of loyal persons qualified for appointment in the civil administration of their colony in India, British education did inadvertently turn out India's first political, academic and industrial elites (Hennessy 1969: 141-44).

Since English was the language of the ruling class and English education 'the gateway to a career in government service or in commerce' (Hennessy 1969: 145), for the caste groups which were already enjoying higher status it became an imperative instrument of maintaining their status. Because of the initial advantage of their high status, the advantages of English education also accrued to these upper castes (M.S.A. Rao 1967: 130-31 and Hennessy 1969: 145-48). ${ }^{4}$

The entry of non-Brahmins to higher education, or for that matter to education itself, was rather late. Not only were these castes indifferent but also the government showed little interest in the education of the numerous non-backward castes till the second quarter of the twentieth century. Even those non-Brahmin castes which made use of education in course of time were of urban background and had a tradition of literacy. The two nonBrahmin castes which have taken a lead over other 'backward' castes in higher education in Karnataka, the Lingayats and Vokkaligas, are the two dominant and wealthy castes, which provided most of the leadership to the non-Brahmin movement in the state, because they 'had a vested interest in the Movement and the fruits it yielded.' The latent consequence of the Backward Classes Movement or the non-Brahmin movement in Karnataka, which in actuality turned out to be a 'movement of the dominant non-Brahmin castes', was the painfully slow progress of the 'real' backward classes and the depressed castes (Chitra 1972: 166-67 and 17071, and Dushkin 1974).

${ }^{4}$ For the historical pattern of Brahmin dominance, from the beginning of the nineteenth century to independence, and the way new education reinforced their status in a princely state, see Chitra (1972). 
It is obvious then that there has been 'a tendency towards monopolistic competition .... in education. Simultaneously with the expansion of education into sections of the population never before touched by it, the edge that the Brahmin and other upper castes have is maintained' (Gusfield 1963: 23), and 'Brahmins are still a force to reckon with in the field of education' (Madan and Halbar 1972: 144).

While our analysis has indicated caste to be a significant determinant of chances for education, it has been argued that:

.. the significance of caste as a determinant of educational opportunity has been over-emphasized. Caste is significant not in itself but because of the congruence between caste, rank and economic position (Ahmad 1974: 183-84).

Let us proceed, then, to these latter sorts of designants of social status, specifically the educational, occupational and income background of the family, in relation to admission to the institutions of higher education. ${ }^{5}$

\section{Educational Background of the Family}

The educational level of the parents of students in the sample is presented in Table 2. The various educational qualifications are classified into three categories:

1. Poor Education:

2. Medium Education:

3. High Education:
Lower secondary and below.

Matriculation and intermediate.

Graduation and above.

A majority of 58.14 per cent of the students in the sample have university educated fathers, 33.43 per cent being post-graduates. Only 3.78 per cent of the fathers have had no formal schooling.

Course-wise, a higher percentage of the fathers of medical students (69 per cent) have had high education than the fathers of research scholars (52.27 per cent) or post-graduate students (39 per cent). Institution-wise, a higher percentage of the fathers of the private medical college students (74.67) have had high education compared to the fathers of students in the government medical college (65.6 per cent). Sex-wise, women students have more educated fathers. Further, a higher percentage of fathers of nonHindu students have had high education than of Hindu students. Castewise, nearly 75 per cent of highly educated fathers are Brahmins.

Concerning the mothers' education, nearly 17 per cent of them have had high education and another 40 per cent have had medium education. Course-wise comparison reveals almost the same pattern observed with

${ }^{5}$ In view of certain forces undermining any assumption of congruence among these variables, it is thought advisable here to es shew the construction of an Index $c$ Social Status, and therefore, treat the variables discretely. 
reference to the educational level of the fathers. As regards sex, it is seen that predominantly it is women students in the sample who have mothers who themselves have been exposed to education; and, as in the case of father's educational level, women students tend to have relatively more educated mothers than do men students.

TABLE 2

EDUCATIONAL BACKGROUND OF THE FAMILY

\begin{tabular}{|c|c|c|c|c|c|}
\hline & $\begin{array}{l}\text { Research } \\
\text { Scholars }\end{array}$ & $\begin{array}{l}\text { Post- } \\
\text { Graduate } \\
\text { Students }\end{array}$ & $\begin{array}{l}\text { Private } \\
\text { Medical } \\
\text { College } \\
\text { Students }\end{array}$ & $\begin{array}{l}\text { Government } \\
\text { Medical } \\
\text { College } \\
\text { Students }\end{array}$ & Total \\
\hline \multicolumn{6}{|l|}{ A. Father's } \\
\hline $\begin{array}{l}\text { High } \\
\text { education }\end{array}$ & 52.3 & 390 & 74.7 & 65.6 & 58.1 \\
\hline $\begin{array}{l}\text { Medium } \\
\text { education }\end{array}$ & 27.3 & 41.0 & 16.0 & 26.4 & 28.5 \\
\hline $\begin{array}{l}\text { Poor } \\
\text { education }\end{array}$ & 20.4 & 19.0 & 8.0 & 8.0 & 12.8 \\
\hline Others & - & 1.0 & 13 & - & 0.6 \\
\hline $\begin{array}{l}\text { B. Mother's } \\
\text { High }\end{array}$ & & & & & \\
\hline $\begin{array}{l}\text { education } \\
\text { Medium }\end{array}$ & 6.9 & 7.0 & 38.7 & 15.2 & 16.9 \\
\hline $\begin{array}{l}\text { education } \\
\text { Poor }\end{array}$ & 38.6 & 27.0 & 48.0 & 48.0 & 40.7 \\
\hline education & 54.5 & 66.0 & 13.3 & 36.0 & 42.1 \\
\hline Others & - & - & - & 0.8 & 0.3 \\
\hline
\end{tabular}

With nearly 60 per cent of the fathers and 17 per cent of the mothers of the sample students having attained high educational level and nearly 25 per cent more of the fathers and 52 per cent of the mothers having attained medium educational level, we can conclude that a majority of the students in higher education tend to come from families which have already attained high or medium educational levels. Considered the other way, compared with the less educated parents, the highly educated ones send more of their daughters into higher education; send more of their progeny into medicine and, to a lesser extent, into research, technology and liberal sciences; and send them into the private rather than the government medical college.

\section{Occupational Background of the Family}

The significance of occupation as a social background variable can hard- 
ly be exaggerated. However, there is as yet no single classification of occupations which will serve all purposes, in all contexts and at all times. Any attempt to construct such an exhaustive classification would only be a 'nominal' categorization, devoid of any heuristic significance. Consequent$\mathrm{ly}$, it is the nature of the data and the purpose of the researcher that determine how a researcher classifies the various occupations. In view of this, the occupational background of the sample students has been classified as follows:

1. Manual occupations:

2. Medium occupations:

3. High occupations:
Factory workers and agricultural labourers.

Lower administrators and clerks. Executives, professionals, landlords and big businessmen.

An overwhelming majority ( 84.60 per cent) of the students have fathers with high occupations, which involves money or power or prestige or all of them. Of them 30.53 per cent are executives and 31.11 per cent professionals. Only 8.72 per cent of the students have fathers who are clerks

TABLE 3

OCCUPATION OF THE FATHER

\begin{tabular}{lccccc}
\hline & $\begin{array}{l}\text { Research } \\
\text { Scholars }\end{array}$ & $\begin{array}{c}\text { Post- } \\
\text { Graduate } \\
\text { Students }\end{array}$ & $\begin{array}{l}\text { Private } \\
\text { Medical } \\
\text { College } \\
\text { Students }\end{array}$ & $\begin{array}{l}\text { Government } \\
\text { Medical } \\
\text { College } \\
\text { Students }\end{array}$ & Total \\
\hline $\begin{array}{c}\text { High } \\
\text { occupation }\end{array}$ & 84.1 & 83.0 & 90.7 & 82.4 & 84.6 \\
$\begin{array}{c}\text { Medium } \\
\text { occupation } \\
\text { Manual } \\
\text { occupation }\end{array}$ & 13.6 & 14.0 & 2.7 & 6.4 & 8.7 \\
$\begin{array}{c}\text { Others } \\
\text { Sthers }\end{array}$ & - & 1.0 & 1.3 & 1.6 & 1.2 \\
\hline
\end{tabular}

and the percentage of workers' children in higher education is a negligible 1.16. Significant differences are observed course-wise. The medical students have more fathers who are professionals or executives (67.5 per cent) than do research scholars (56.36 per cent) or post-graduate students $(52.0$ per cent). More children of rural landlords or big businessmen are drawn into the post-graduate course than into research or medicine.

As regards the occupation of the mothers of students, only 38 (or 11.05 per cent) are employed. Thirty-three of these 38 are professionals (one is 
an administrator), i.e., have high occupations, and none has a manual occupation. Thirty-two out of $3 \&$ students who have working mothers are in medicine, 22 in the private medical college.

These findings indicate that an overwhelming majority of the sample students come from high occupational background and nearly 10 per cent of them have both their parents in high occupations. Course-wise, more of medical students tend to come from high occupational background followed by research scholars and post-graduate students. Institution-wise, the private medical college seems to attract more students from high occupational background compared to the government medical college.

\section{Family Income Background}

In spite of certain methodological problems arising out of its computation and reliability, family income constitutes a significant indicator of social status. The information about monthly family income ${ }^{6}$ of the respondents was originally collected under ten categories, and later on, based on the mean income of the sample, they were recategorized for analytical purposes as follows:

1. Poor income:

Rs 750 and below.

2. Medium income:

Rs 751 to 1500 .

3. High income:

Rs 1501 and above.

It is seen that an overwhelming majority of 71.81 per cent of the total sample students come from families whose monthly income exceeds Rs 1000. In terms of our analytical categories, it is seen that while 27.62 per cent of the sample students come from high income families, 44.19 per cent belong to medium income families, and 25.0 per cent come from poor income families.

TABLE 4

FAMILY INCOME

\begin{tabular}{llllll}
\hline & $\begin{array}{l}\text { Research } \\
\text { Scholars }\end{array}$ & $\begin{array}{l}\text { Post- } \\
\text { Graduate } \\
\text { Students }\end{array}$ & $\begin{array}{l}\text { Private } \\
\text { Medical } \\
\text { College } \\
\text { Students }\end{array}$ & $\begin{array}{l}\text { Government } \\
\text { Medical } \\
\text { College } \\
\text { Students }\end{array}$ & Total \\
\hline $\begin{array}{c}\text { High } \\
\text { income }\end{array}$ & 25.0 & 20.0 & 41.3 & 26.4 & 27.6 \\
$\begin{array}{c}\text { Middle } \\
\text { income } \\
\text { Poor } \\
\text { income } \\
\text { No response } \\
\text { \& others }\end{array}$ & 45.5 & 46.0 & 42.7 & 43.3 & 44.2 \\
\hline
\end{tabular}

'Family income is defined here as the sum total of the income per month from all sources, of fathers and the contributions, if any, of any other earning member. 
With the mean income of the sample being Rs 1207.20 and with nearly 40 per cent of the students coming from income background above the mean income group (Rs 1001-1250), the generally higher income background of the students in our sample is proved.

However, it is important to note that there are significant course- and institution-wise differences. While the mean family income of the parents of medical students is Rs 1342.80 (Rs 1537.50 for the private medical college students and Rs 1148.10 for the government medical college students), that of research scholars and post-graduate students are Rs 1175.00 and Rs 980.30 respectively. The course and institutional differentials in the income background of the students is also confirmed by the data presented in Table 4.

In general it could be said that students in higher and professional education tend to come from economically sound background, though income as a factor is not as significant as educational and occupational background of the family. Course-wise, medical students are again a select group, followed by research scholars and post-graduate students. And private medical college students are still more select than the government medical college students.

\section{Rural-Urban Background}

The urban bias of the Indian educational system is well known and manifests itself in various ways; here we shall examine the rural-urban background of students in our sample.

TABLE 5

RURAL-URBAN BACKGROUND

\begin{tabular}{|c|c|c|c|c|c|}
\hline & $\begin{array}{l}\text { Research } \\
\text { Scholars }\end{array}$ & $\begin{array}{l}\text { Post- } \\
\text { Graduate } \\
\text { Students }\end{array}$ & $\begin{array}{l}\text { Private } \\
\text { Medical } \\
\text { College } \\
\text { Students }\end{array}$ & $\begin{array}{l}\text { Government } \\
\text { Medical } \\
\text { College } \\
\text { Students }\end{array}$ & Total \\
\hline Rural & 22.3 & 24.0 & 17.3 & 1.6 & 14.8 \\
\hline Urban & 72.7 & 76.0 & 82.7 & 98.4 & 85.2 \\
\hline
\end{tabular}

An overwhelming majority of 85.13 per cent of the students in our sample are urbanites, ${ }^{7}$ having lived in cities or towns for the most part of their life till now, and only 14.83 per cent of them come from rural areas.

${ }^{7}$ Following census definitions, both towns and cities are classified as urban areas and the place of father's occupation and the place of respondent's previous education have been used in determining the area of origin. 
Medical education seems to be a virtual monopoly of the urbanites. Even the few students from rural areas find better representation in the private medical college compared to the government medical college. The almost cent per cent representation of urbanites in the government medical college sample is understandable since it attracts predominantly students from the city wherein it is located. Rural students are better represented in research and post-graduate courses (especially of the liberal science type).

Insofar as greater informational density of all sorts is characteristic of urbanism generally, the strong propensity of the urban dwellers to obtain higher education would seem to be related to their greater awareness of the educational and occupational possibilities concentrated there than are those raised in rural areas (see Rajagopalan and Jaspal Singh 1968: 5).

\section{Type of Schooling}

It is a matter of common observation that "their exists a hierarchy of educational institutions with respect to the standard and quality of education imparted by them to the students' and that 'individuals belonging

TABLE 6

TYPE OF SCHOOLING

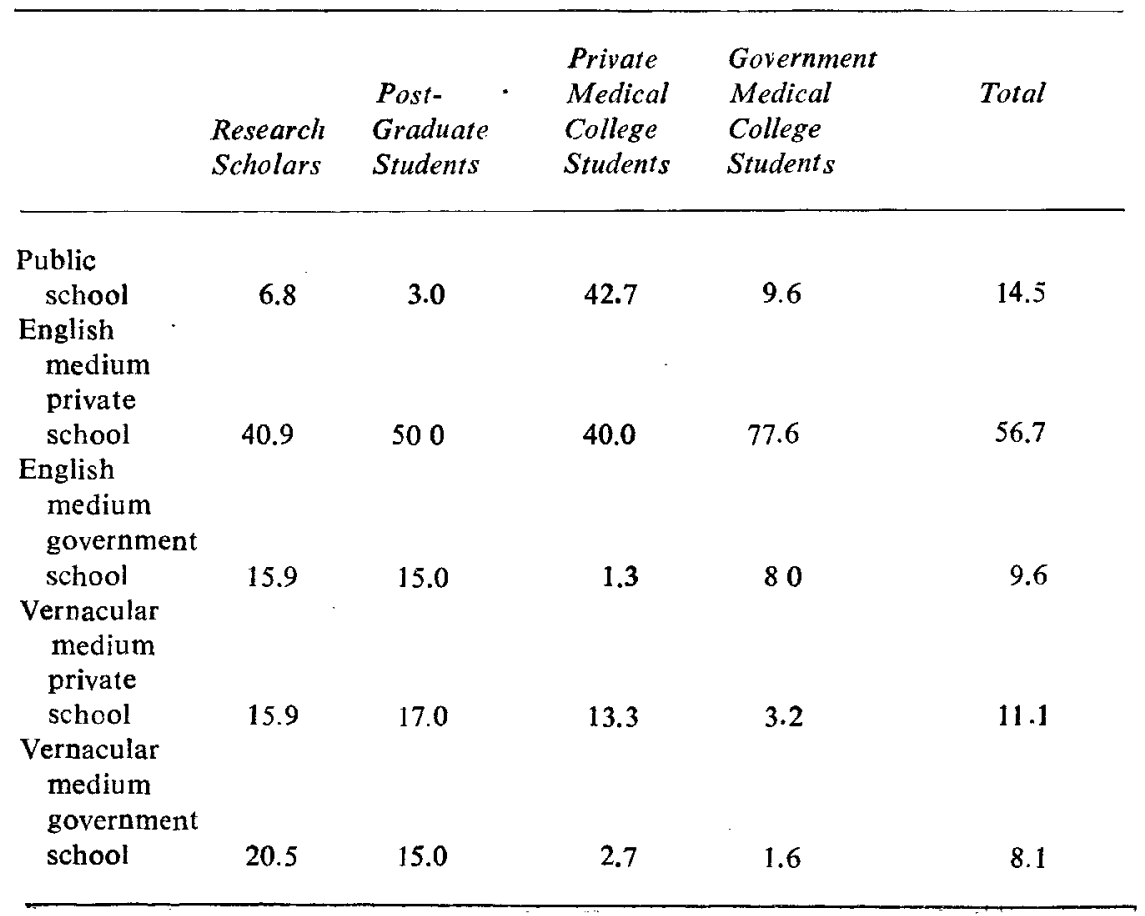


to a certain strata (sic) are better able to exploit educational facilities of a higher quality than those belonging to others' (M.S.A. Rao 1967: 135 and 127). We shall here examine the extent to which the type of schooling and the medium of instruction tend to act as an advantage of handicap in securing admission to higher and professional education.

The type of schooling that our sample students have had falls into five categories based on their status, the nature of management and the medium of instruction:

1. Public schools

2. English medium private schools

3. English medium government schools

4. Vernacular medium private schools

5. Vernacular medium government schools

These five categories constitute a hierarchy of school education.

It is seen that a majority of 56.69 per cent of our sample students have had English medium private school education and only 8.14 per cent vernacular medium government school education. Considering the fact that there were only 44 public schools in the whole of India in December 1969 (R. P. Singh 1972:21), it is significant to note that as many as 14.53 per cent of our sample students have had public school education.

An overwhelming majority of 80.81 per cent of our sample students have had English medium education, only 19.19 in the vernacular: clearly, English medium schooling is important for entering higher and professional education.

Ignoring the medium of instruction at school, it is seen that only 17.73 per cent of the students in higher education come from schools which are managed by government or allied bodies, which indicates the disadvantage a government school student faces in entering higher education, especially in comparison with public school products.

Medical students again are observed to be a select group. Of the $\mathbf{5 0}$ students educated at the public schools, as many as 44 are pursuing medicine. Course-wise comparison yields the same findings. Similar differences are observed with reference to the nature of institutions, i.e., the private medical college students have had better schooling compared with those in the government medical college.

With a little over 80 per cent of the total sample students coming from the English medium schools and as many as nearly 15 per cent of the students having had public school education, it could be concluded that students in higher and professional education tend predominantly to come from English medium schools, considered to have higher standard and status. This seems to be more true in the case of medical students than that of research scholars of post-graduate students.

It is clear then that public school and English medium school students 
are in an advantageous position in gaining admission to higher and professional education. In the light of the observation that 'the social background of students operates as a selective factor in their admission to qualitatively different types of educational institutions' (M.S.A. Rao 1967: 137), and that it is a minority of the higher stratum of society which goes through the public school and English medium education, its role in perpetuating the privileges of a few people becomes clear.

\section{SUMmary AND TRENDS: 'Status Retention'}

We have analyzed the social origins of students in institutions of higher and professional education in a metropolis. Though several variables were considered discretely, the findings seem to fit into a consistent pattern, thereby allowing us to comprehend the emerging trends and implications.

Indian educational system, especially at the higher level, is characterized by an urban bias. Most institutions of higher learning are concentrated in urban areas, and the awareness of their existence and importance is also greater there. Consequently, admission to these institutions tends to be almost entirely biased in favour of students from urban areas, though urban population is small in comparison to the rural.

Even though admission to higher and professional education is, in principle, based strictly on merit, and no apparent artificial restrictions are imposed, in actuality, it is found to be determined by a set of nonacademic and socio-economic factors.

In spite of various formal and informal attempts to curb their monopoly in the domain of education, Brahmins (a small minority among the Hindus), the traditionally privileged class and the first to make use of modern education, still continue to be the 'dominant caste' in the academic world. Of course, some non-Brahmin castes have recently found their way into the field of education. But it is only the dominant among them who have benefited from the educational expansion as also from the formal measures to break the Brahmin monopoly in education. Part of this trend is at least explained by the political power which they have been able to wield and exploit. The progress of education among the lower castes, especially among the scheduled castes, seems to be painfully slow and halting.

Among the non-Hindus, Christians (especially, the Roman Catholics) seem to be educationally privileged. While their contribution to the cause of educational development in the country should be recorded with appreciation, we cannot be blind to the bias and favouritism to which they have succumbed. They are demonstrably being imitated by some of the caste and community groups in Karnataka. In fact, government institutions are found to be more egalitarian compared to the private ones, notwithstand- 
ing the tall claims which the latter make (see Madan and Halbar 1972).

An important consideration in obtaining urban higher education is the ability to afford it-which involves both direct and 'opportunity' costs. A majority of students in higher education comes from families in which fathers (and in some cases even mothers) are placed in high occupations. There are a few students from the rural areas, and their fathers are more likely to be landlords. In brief, students in higher education tend to come from relatively higher income families.

Besides, a favourable educational environment at home seems to be an important factor influencing admissions to higher and professional education. Students tend predominantly to come from families with high educational background.

Inequality of educational opportunity, however, does not take place solely or abruptly at the level of higher education. In fact, the initial selection takes place at the school level itself and higher education mainly reinforces it. An overwhelming majority of the students in higher education have had English medium education and in privately managed schools. The public schools, a very small number in the Indian school system, contribute disproportionately to the ranks of higher education. To the extent that the students who have had such schooling belong to higher strata of the society, it tends to act as greenhouses for stabilizing the already privileged.

Again, despite the rapid expansion in women's education, their presence in higher education is still small; and a majority of even this small percentage comes from the higher strata.

While our findings have been unequivocal in highlighting the influence of certain non-academic and socio-economic factors in recruitment in general, these factors are all the weightier in professional education like medicine, which is most in demand: while students in higher education are generally a select group, medical students are an elite within it.

The foregoing analysis calls into serious question the role of education in vertical social mobility and the common assertions regarding the emergence of a more egalitarian society. With widespread inequality in opportunities for education, resulting from the operation of socioeconomic factors, education seems to have failed as an effective equalizing factor. Instead, the evidence points to the long term strategies-widely understood and employed in a certain stratum-by way of choice of schools and colleges, intended to help the next generation to retain or transcend the parental levels of income, wealth and status. While these strategies apply across the board, their intensity becomes particularly acute in occupations which carry the greatest rewards and esteem, for example the upper reaches of politics, the corporate commercial-industrial world, the cadred civil service, and some of the modern professions. This problem has not attracted much 
attention of the sociologists working on India.

In this context, the concept that appears to be significant is that of status retention, which is sometimes confused with the residually defined idea of 'non-mobility'. This concept is as yet unrefined and subsumes many important characteristics, and one of them is occupational inbreeding. This carries an element of heredity into the heart of modern occupations, which has marked implications for structural rigidity; and so I proceed to examine the pattern of occupational inbreeding among medical students.

\section{Occupational Inbreeding among Medical Students}

My data on occupational inbreeding come from the medical students in my sample $(\mathrm{N}=200)$ and concern the members of their families already in the medical profession. This information was collected at two levels of family organization, namely the first degree relations, i.e, the student's father's nuclear family, and then a wider level reaching a maximum of four degrees of relationship with the student. It suffers, of course, from the limitation of being restricted to only one of the two dimensions of the problem noted by Kelsall (1954: 309), as it considers only those among the entrants to the medical course who themselves have parents or near relatives in that profession.

TABLE 7

PATTERN OF OCCUPATIONAL INBREEDING

\begin{tabular}{lc}
$\begin{array}{l}\text { Degree of } \\
\text { Relationship }\end{array}$ & $\begin{array}{l}\text { Number of Relatives } \\
\text { in Medical Profession }\end{array}$ \\
\hline First & 58 \\
Second & 79 \\
Third & 127 \\
Fourth & 59 \\
Total & 323 \\
Total number of & \\
$\quad$ students having & 123 \\
$\quad$ relatives & \\
Average number of & 2.63 \\
$\quad$ relatives per student & \\
\hline
\end{tabular}

It is seen that at the wider level 61.5 per cent of the medical students have a relative who is a doctor or surgeon. The maximum number of relatives any student has in the medical profession is seven. In all 123 students have a total of 323 relatives within four degrees in the medical 
profession, giving an average of 2.63 relatives per student. Thus, a pronounced tendency for occupational inbreeding is discernible at the wider level of family organization. The fact that as many as 38.5 per cent are first generation medical students in the wider family circle may suggest that medical profession is not all that rigid, but this has to be set against the phenomenal growth of medical education, especially during the last two decades or so.

Only 22.5 per cent of the students, however, have first degree relatives in the medical profession: occupational inbreeding within the nuclear family appears to be modest, yet noteworthy. Furthermore, of the 344 students in the overall sample, the fathers of 27 and the mothers of 5 are in medicine, and all but one of these 32 students are studying medicine. Again, 65 medical students ( 32.5 per cent of the medical sample) have a relative within four degrees who is currently studying medicine; they have 96 such relatives, giving an average of 1.47 relatives per student. In brief, there seems to be a strong and pronounced tendency for occupational inbreeding in medical profession, within and beyond the nuclear family. A sound economic foundation, a certain sub-cultural background, and strong home-reinforcement contribute to this tendency.

In view of 'anticipatory socialization', it is much easier for children and close kinsmen of doctors to seek, pursue, and succeed in medical education, and later in a medical career. They cannot only draw upon the experience and awareness of their close kin concerning the steps prerequisite to entering the occupation, but also gain later the necessary social and economic support, especially by inheriting goodwill. On both these counts, those who are the first in their kin circle to seek to enter the profession are at a decided disadvantage.

The great popularity of the medical course calls for some comment here. Anxieties surrounding health, sickness, and death open up rather large possibilities of income and status in private practice. Not only does this persuade an older generation to canalize-or to try to canalize-the next generation into the familiar profession, it also serves to entice others whose families have all along been outside. In response to the resulting large pressure for admissions - to appear to be just and orderly! - the procedures are highly bureaucratized, with elaborate rules and regulations, imposing several constraints both formal and informal, material and non-material, upon the candidates. But the ambitious and the capable manage to neutralize this bureaucratization via capitation fees and such other devices as the use of political influence, writs in the court, etc. Cumulatively, these procedures imply higher inputs of a sort other than the traditional effort at learning; and only a very small section of society is capable of making these inputs.

The net consequence of the foregoing is that doctors are drawn over- 
whelmingly from the upper social stratum (see Madan 1972 and Dubey 1975: 59-75), a point very strongly supported in our analysis of the social origins of students: the medical students are an elite within the highly select ranks in higher education, being drawn almost exclusively from the high educational, occupational and income backgrounds (see also Sharadamma and Parvathamma 1968).

Students who make these high inputs are necessarily 'capitalistic' in orientation, expecting early and adequate returns on their investment. This is reflected in the common complaints about declining altruism and the increasingly unprofessional ways of making money in the profession. Our doctors' stubborn resistance to rural areas, their strong attachment to urban areas, and their indefatigable search for emigration possibilities ${ }^{8}$ are also part of the same syndrome. In brief, the functioning of medical education in India illustrates the far-reaching implications of a much more general mechanism of status retention or stability.

\section{CONCLusion}

This paper has sought to examine the role of higher education in stabilizing the structure of inequalities and of status in a metropolis. Approaching the problem first by analyzing the social origins of students in higher education and then by examining more closely the pattern of occupational inbreeding among medical students, we found that higher education functions as a status stabilizer, contributing to status retention in urban areas.

This may appear to be paradoxical in the light of rapid expansion of education and industrialization in the country since Independence. Though some people from the lower strata are more educated and better employed than they were a few decades back, mainly because of the widening opportunities in education and occupation, it remains a stubborn fact that the relative advantage of the upper stratum and the informal barriers to the higher status occupations have not only persisted but also become strengthened (see Saberwal 1975: 191-92).

Such an inegalitarian and elitist educational system with potentialities for stabilizing social status is not recent. Social scientists, especially of the Marxist sort, trace the situation to the nature of the pre-Independence national movement and to the dynamics of the political system in operation since then (see, e.g., Sen 1971 and Bhattacharya 1975).

Since we are educating now for twenty years later, this inegalitarian and elitist system of education will have profound effects on social structure for decades to come. Yet, the efforts at redeeming the educational situation

${ }^{8}$ The proclivity for brain drain is found to be pronounced among medical students in the sample (Jayaram 1976: Ch 8, 365.68). 
in India have inevitably operated within the established framework. It is now being realized, however, that 'our educational problems cannot be resolved sui generis, i.e., in the context of educational institutions alone' (Saberwal 1972: 409), and a thorough-going egalitarian transformation of the society seems to be a prerequisite for any meaningful change in the realm of education.

\section{$R E F E R E N C E S$}

AmMAD, KARUNA. 1974. Women's higher education: recruitment and relevance. In Amrik Singh and Philip G. Altbach, eds., The higher learning in India. Delhi: Vikas Publishing House. pp. 180-201.

BHATTACHARYYA, BudDHADEVA. 1975. Radical reconstruction of education-which way? In Satish Saberwal, ed., Towards a cultural policy. Delhi: Vikas Publishing House.

BoUDON, RAYMOND. 1974. Education, opportunity and social inequality. New York: John Wiley and Sons.

CHITRA, M.N. 1970. The social background of some undergraduate women students in Mysore city. Unpublished Ph.D. Thesis, University of Delhi.

- 1972. Higher education and society in Mysore under British rule. Sociological bulletin (New Delhi) 21: 152-75.

De SouzA, Alfred. 1974. Indian public schools: a sociological study. New Delhi: Sterling Publishers.

DI BONA, JOSEPH. 1970. Modernizing and parochialization in Indian higher education: the role of the university in facilitating rural-urban mobility. In Richard G. Fox, ed., Urban India: society, space and image. North Carolina: Duke University Press.

Dubey, S. M. 1975. Social mobility among the professions. Bombay. Popular Prakashan.

DUSHKIN, LeLAH. 1974. The non-Brahman movement in princely Mysore. Unpublished Ph.D. Thesis, University of Pennsylvania.

Floud, JEAN and A.H. HALSEY. 1965. In A.H. Halsey et al., ed., Education, economy and society. New York: The Free Press.

Foster, PhILlP. 1971. Access to schooling. In Don Adams, eds., Education in national development. London: Routledge and Kegan Paul.

GORE, M.S. et al. 1970. Field studies in the sociology of education-all India report. New Delhi: N.C.E.R.T.

GUSFIELD, JOSEPH. 1963. Education as a social dynamic in underdeveloped countries. In Sureshchandra Shukla, ed, The context of education in developing societies. Delhi: Central Institute of Education (N.C.E.R.T.).

HENNESSY, JOSSLEYN. 1969. British education for an elite in India (1780-1947). In Rupert Wilkinson, ed., Governing elites. New York: Oxford University Press.

HoODA, S.S. 1968. The Bombay collegian. Unpublished Ph. D. Thesis, University of Bombay.

HUSEN, TORSTEN. 1970. The effect of school structure upon utilization of ability. In D.F. Swift, ed., Basic readings in the sociology of education. London: Routledge and Kegan Paul. 
JAYARAM, N. 1976. Education and social structure. Ph.D. Thesis submitted to Bangalore University.

JORAPUR, P.B. 1971. Intergenerational occupational mobility. The Indian journal of social work (Bombay) 31: 461-67.

Kel.SALL, R.K. 1954. Self recruitment in four professions. In D.V. Glass, ed., Social mobility in Britain. London: Routledge and Kegan Paul.

KHUSRo, A.M. 1967. A survey of living and working conditions of students of the university of Delhi. Bombay: Asia Publishing House.

KING, A.D. 1970. Elite education and the economy-IIT entrance: 1965-70. Economic and political weekly (Bombay) 5: 1463-72.

MADAN, T.N. 1972. Doctors in a ncrth Indian city: recruitment, role perception, and role performance. In Satish Saberwal, ed., Beyond the village: sociological explorations. Simla: Indian Institute of Advanced Study.

MADAN, T.N. and B.G. HAlbar. 1972. Caste and community in the private and public education in Mysore state. In S.H. Rudolph and L.I. Rudolph, eds., Education and politics in India. Delhi: Oxford University Press.

Mehta, RAMA. 1970. The western educated Hindu woman. Bombay: Asia Publishing House.

MISRA, B. B. 1961. The Indian middle class. London: Oxford University Press.

MYrdal, GunNar. 1968. Asian drama. Harmondsworth, Middlesex: Penguin Books.

PALMIER, Leslie. 1967. Educational systems of southern Asia and social stratification. In M.S. Gore et al., eds., Papers in the sociology of education in India. New Delhi: N.C.E.R.T.

Rajagopalan, C. and JASpal Singh. 1968. The Indian institutes of technology-do they contribute to social mobility? Economic and political weekly (Bombay), reprint pp. 1-5.

RAO, M.S.A. 1967. Education, social stratification and mobility. In M.S. Gore et al., eds., Papers in the sociology of education in India. New Delhi: N.C.E.R.T.

RAO, V.K.R.V. 1961. University education and employment. Bombay: Asia Publishing House.

RUDOLPH, S.H. and L.I. RudolPH, eds., 1972. Education and politics in India. Delhi: Oxford University Press.

SABERWAL, SATISH. 1972. Education and inequality: an essay in political sociology. Economic and political weekly (Bombay) 7: 409-12.

- - 1975. Education, inequality and industrialization. Journal of higher education (New Delhi) 2: 189-97.

SEN, AMARTYA. 1971. The crisis in Indian education. In S.C. Malik, ed., Management and organization of Indian universities. Simla: Indian Institute of Advanced Study.

SHAH, B.V. 1961. Gujarati college students and caste. Sociological bulletin (New Delhi) 10: 41-60.

Sharadamma, S. and C. Parvathamma. 1968. Some aspetts of socioeconomic and political background of medical students in Mysore. Arts journal of the Mysore university (Mysore) 24: 49-56.

SHARMA, BALDEV R. 1972. What makes a manager-merit, motivation or money? Economic and political weekly (Bombay) 7: M51-66.

_- 1976. Professionals in the making: their social origin. Economic and political weekly (Bombay) 11: M5-10.

SingH, R.P. 1972. The Indian public school. New Delhi: Sterling Publishers.

SoVANI, N.V. 1966. Occupational mobility in Poona city between three generations. In: Urbanization and urban India. Bombay: Asia Publishing House. 
WARNER, W.L. et al. 1944. Who shall be educated? New York: Harper and Row.

WOLFLE, DAEL. 1965. Educational opportunity, measured intelligence, and social background. In A.H. Halsey et al., eds., Education, economy and society. New York: The Free Press.

Young, MiCHAEL. 1961. The rise of the meritocracy 1870-2033. Harmondsworth, Middlesex: Penguin Books. 